\title{
FROM GRAZ TO LJUBLJANA? TOWARDS DISCOVERY OF THE ORIGIN OF THE HREN CHOIRBOOKS
}

\author{
KLEMEN GRABNAR \\ Muzikološki inštitut ZRC SAZU
}

Izvleček: V Hrenovih kornih knjigah je prisotnih pet različnih pisav. Glavni pisec je bil Georg Kuglmann, ostali pa so neznani. Tri pisave (med njimi Kuglmannova) se med seboj prepletajo in kažejo na obstoj delavnice v Gradcu. Ostali dve pisavi pa nakazujeta, da repertoar ni bil v celoti prepisan v Gradcu. Palestrinova Missa L'homme armé je bila (zaradi uporabljenega papirja) verjetno proti koncu 16. stol. prepisana $v$ Innsbrucku, kratki odpevi $v$ slogu falsobordone pa so bili dodani naknadno, morda v Ljubljani.

Ključne besede: korne knjige, paleografija, kodikologija.

\begin{abstract}
There are five scribal hands evident in the Hren choirbooks. The main scribe for these choirbooks was Georg Kuglmann; the others are unknown. Three scribes (among them, Kuglmann) worked closely together and formed part of a scribal workshop at Graz. The presence of two other scribal hands suggests that not all the repertory was copied in Graz. The Missa L'homme armé of Palestrina was probably copied in Innsbruck in the late sixteenth century (given the paper type), and a few responses in falsobordone style were added in later years, perhaps in Ljubljana.
\end{abstract}

Keywords: choirbooks, paleography, codicology.

The Hren choirbooks have been the object of some scholarly attention, especially in Slovenia, though not yet in a fully detailed manner. ${ }^{1}$ Thus none of the existing studies reports on the manuscripts' paper types, records all the differences of handwriting or lists the contents and concordances entirely accurately. So the intention of this article is, by means of paleographical and codicological analysis, to confirm the Graz origin of these manuscripts, and also to draw attention to a small portion of one of the manuscripts that suggests the presence of an interpolation not originating in Graz. Especial attention is accordingly paid to scribal hands and watermarks, and, to a lesser extent, also to repertory.

The Hren choirbooks are a collection of six well-preserved large codices from the early seventeenth century that today constitute part of the Manuscript Collection at the

1 The principal studies of the Hren choirbooks are Gruber, "Magnificatkompositionen in Parodietechnik," 33-60; Höfler, "Gornjegrajska glasbena zbirka,” 32-35; Škulj, Hrenove korne knjige; and Kokole, "From Graz to Today's Central Slovenia," 335-374. 
National and University Library in Ljubljana (SI-Lnr; they are shelfmarked Mss 339-344). When the manuscripts came to the library in Ljubljana is not clear. However, it is most likely they arrived after the reforms of Joseph II in the late eighteenth century, when the episcopal archives from Gornji Grad were acquired (the library was then called the Lyceal Bibliothek). ${ }^{2}$ They are not listed in the library inventories of the late eighteenth and early nineteenth centuries. Since none of these inventories is a complete listing of library items, they do not argue for a later date of accession. However, the codices were certainly in the library's possession before the last decade of the nineteenth century, since in 1889 Ferdinand Bischoff mentioned their presence there in an article on music in Styria. ${ }^{3}$

As mentioned above, the assumption is that these manuscripts came to the Lyceal Bibliothek from the collection of the Bishop's palace in Gornji Grad. There are two main reasons for this supposition. First, the former owner of at least two of the choirbooks (but as likely as not of all six) was the prince-bishop of Ljubljana, Tomaž Hren (Thomas Chrön). Hren, bishop of Ljubljana from 1597 to 1630, was closely connected with the court in Graz, especially from 1614 to 1621, when he served as governor of Inner Austria, residing at Ferdinand's court. Hren was a great music-lover and personally provided repertoire for his musical establishments both at the cathedral of Ljubljana and at the co-cathedral of Gornji Grad. In Ms 344 we find a dedication stating that the volume was presented to Hren in 1616 by Karl Kuglmann, son of the Graz court bass singer and music scribe Georg Kuglmann, who had written out the choirbook. ${ }^{4}$ It must be noted that beyond this fact there is unfortunately no information on how and when Hren acquired the remaining choirbooks. The other volume once indubitably in his possession is Ms 341, which contains a flyleaf with Bishop Hren's coat of arms and his motto plus name written at the top and bottom of the page, respectively. ${ }^{5}$

Second, if Hren had kept the choirbooks in Ljubljana, they would very likely have been listed in the Ljubljana Cathedral music catalogue entitled Inventarium librorum musicalium ecclesiae cathedralis Labacensis and compiled between 1620 and 1628 by order of Hren himself. ${ }^{6}$

The Hren choirbooks are of large format, measuring ca. $55 \times 40 \mathrm{~cm}$ and containing up to 591 folios. They are all written on good-quality paper, which has mostly not suffered damage from ink corrosion, making all the folios more or less perfectly legible and usable. All the books save one (Ms 342) retain their original leather-over-wood binding in white leather; only one (Ms 339) is bound in dark brown leather. The bindings are blind-tooled in very similar fashion. Since the choirbooks of Graz origin from the same period today preserved in the University of Graz Library (Universitätsbibliothek Graz; A-Gu) display similar blind-tooled bindings, and since there were bookbinders active in Graz, the Hren

2 See Höfler and Klemenčič, Glasbeni rokopisi in tiski, 12-13.

3 Bischoff, "Beiträge zur Geschichte," 139-146.

4 See the reproduction of the relevant folio in Kokole, "From Graz to Today's Central Slovenia," 348.

5 See the reproduction of the flyleaf ibid., 341.

6 Cf. Snoj, Zgodovina glasbe na Slovenskem, 367. 
codices were most probably bound in Graz. ${ }^{7}$ Although we do not know who actually bound the manuscripts, this may well have been the work of Georg Wagner, who in 1610, for instance, received payment for binding Kuglmann's choirbooks. ${ }^{8}$

The manuscripts contain a large repertory of exclusively liturgical music: Masses, Magnificat settings, litanies, psalms, hymns, Marian antiphons and responses. Nearly all the Masses and many of the Magnificats are of parody or imitation type, based on models dating from the period of Josquin to that of Gabrieli. A high proportion of the pieces (mostly by famous composers of the period) were probably copied from existing prints, but some circulated only in manuscript. However, there are also a fair number of unica preserved only in the Hren choirbooks (the majority of these are by composers linked in one way or another to the Graz court).

The first choirbook (Ms 339) contains thirteen Magnificat settings for five to six voices followed by eighteen Masses for four to eight voices, all ordered according to the (ascending) number of voices. This manuscript is especially important on account of the five unica it contains: a Magnificat by an unknown Kleinmeister, Bartholomeus Damitz; a Missa Magne pater Augustine by a little-known Italian composer, Theodorus Leonardus; a Missa Pastores quid nam vidistis (based on the homonymous motet of Clemens non Papa) by the Kapellmeister in Vienna, Jean Guyot; and a Missa Aller mi fault (based on Willaert's similarly named chanson) by the Graz Kapellmeister Simone Gatto; and a Missa Osculetur me by Orlando di Lasso. For a certain length of time the Missa Dulce me mori (based on Sandrin's famous chanson Doulce memoire) by Ippolito Chamaterò, who was active mostly in northern Italy, was likewise regarded as a unicum. This Mass was printed in Chamaterò's Liber primus missarum (Venice: Scotto, 1569), and the only specimen of this collection was formerly reported as missing; however, it has recently been found. ${ }^{9}$ The composer of this Mass preserved in Ms 339 has hitherto been regarded as unknown - a consequence of the erroneous transcription of his surname (as Lammaterus instead of Cammaterus). ${ }^{10}$

The second choirbook (Ms 340) is a collection of twelve settings of the Ordinary of the Mass ordered according to the (descending) number of voices, from eight to four voices. Three unica appear in this manuscript: a Missa Benedicite omnia opera Domini by the Graz organist Annibale Perini; a Missa Quanto in milli anni in ciel (based on Nolett's madrigal) by Bartolomeo Spontone, active in northern Italy; and a Missa Stabunt iusti (based on Lasso's motet) by Simone Gatto.

The third choirbook (Ms 341) contains eighteen Magnificat settings and eighteen Masses ordered in alternation and descending from ten to five voices, ${ }^{11}$ plus a few responses

7 See, for example, A-Gu, Ms 8. A portion of this choirbook was likewise copied by Georg Kuglmann.

8 Federhofer, Musikpflege, 96.

9 Kurtzman and Schnoebelen, Catalogue of Mass. In Liber primus missarum the Mass is titled Missa ad Illustrissimum Parmae et Placentiae Ducissam.

${ }^{10}$ See Škulj, Hrenove korne knjige, 14 and 40.

${ }^{11}$ Interestingly, A-Gu, Ms 22, another choirbook from Graz, is organized in similar manner. Georg Kuglmann dedicated it in 1607, each pair comprising a Mass and a Magnificat being offered to a different prominent person in Seckau: "Georg Kugelmann, erzherzgl. Kapellensinger, widmete 
for four voices. This codex is next to Ms 339 probably the best-known one among the Hren choirbooks, since it contains a unicum by Lasso: a Magnificat septimi toni for ten voices. Besides Lasso's Magnificat, this choirbook contains six further unica: a Missa and a Magnificat by the Graz Hofkapellmeister Pietro Antonio Bianco (both works are based on Giovanni Croce's motet Percussit Saul mille); a Missa Nasce la pena mia (based on Striggio's famous madrigal) by Spontone; a Missa Invidiosa amor (based on another Striggio madrigal) by a musician in the Bavarian Hofkapelle, Antonius Gosswin; a Missa Nisi Dominus aedificaverit domum (based on Lasso's motet) by Giovanni Flori, active in Catholic south Germany and Italy; and a Magnificat primi toni by Gatto. To these, an anonymous versicle and 3 responses in falsobordone style should be added.

The fourth choirbook (Ms 342) is a collection of two five-voice settings of the Ordinary of the Mass: one by Jacob Regnart and the other by Gatto.

The fifth choirbook (Ms 343) contains thirty-eight psalms, seventeen Magnificats, thirty-one hymns and two Masses for eight to fourteen voices. There are thirty-six unica present in this manuscript: three psalms by Spontone (Dixit Dominus, Confitebor tibi Domine and Beatus vir); a Magnificat secundi toni by Lambert de Sayve, a musician active in Graz, Prague, Linz and Vienna; a complete cycle of hymns for the liturgical year (thirty-one in number) by the Graz court organist Francesco Stivori; and a Missa Exaudi Deus (based on Gabrieli's motet) by de Sayve.

The final and sixth choirbook (Ms 344) is a collection of litanies for two choirs (comprising four and six voices, respectively) and Marian antiphons for five voices. This contains a single unicum: a five-voice Marian antiphon, Ave Regina coelorum, by Bianco.

It is well established that the main scribe of these choirbooks was the Graz court bass singer Georg Kuglmann, active as a scribe at least from 1587 until his death in 1613 or 1616 , and that other scribal hands are also evident. ${ }^{12}$ However, no detailed examination has previously been undertaken.

Through analysis of the scribal hands in detail it becomes sufficiently evident that the Hren choirbooks are the work of five different scribes (see Table 1). As has already been ascertained, especially by Gernot Gruber, Mss 343 and 344 are unquestionably the work of Kuglmann (see Figs. 1 and 2). Ms 339 has similarly been attributed to him alone, although in fact three further scribal hands are discernible.

The copying of Ms 339 was clearly begun by the first scribe (Scribe A), who was responsible for entering the Magnificats (see Fig. 3). A different hand, that of Kuglmann, took over to copy the first four Masses (see Fig. 4). A third hand (Scribe B) then copied most of the next Mass (see Fig. 5), towards the end alternating with Kuglmann. After that, Kuglmann copied another Mass alone. The next Mass (Palestrina's Missa L'homme armé for five voices) stands apart from the rest; it is in a completely unrelated hand (Scribe $\mathrm{C}$; see Fig. 6). Scribe B took over to copy the next Mass. There follow four more Masses,

je eine Missa u. ein Magnificat der Hs. dem Bischof v. Seckau, Martin [Brenner], dem Propst v. Seckau Sebastian [Kueler] u. den Chorherren daselbst: Georg Huebner, Zacharias Schwedlinger, Michael Bruchlinger, Georg Harb, Franz Nomander, Paul Faber, Clemens Reichel u. Balthasar Polzmann." See Zotter, "Der Handschriftenkatalog der UB Graz."

${ }^{12}$ For a list of the principal studies, see earlier, n. 1. 
all copied by Kuglmann. The next Mass was copied by Scribe A. The remainder of the manuscript is all in Kuglmann's hand.

Table 1 A comparison of scribal hands in the Hren choirbooks

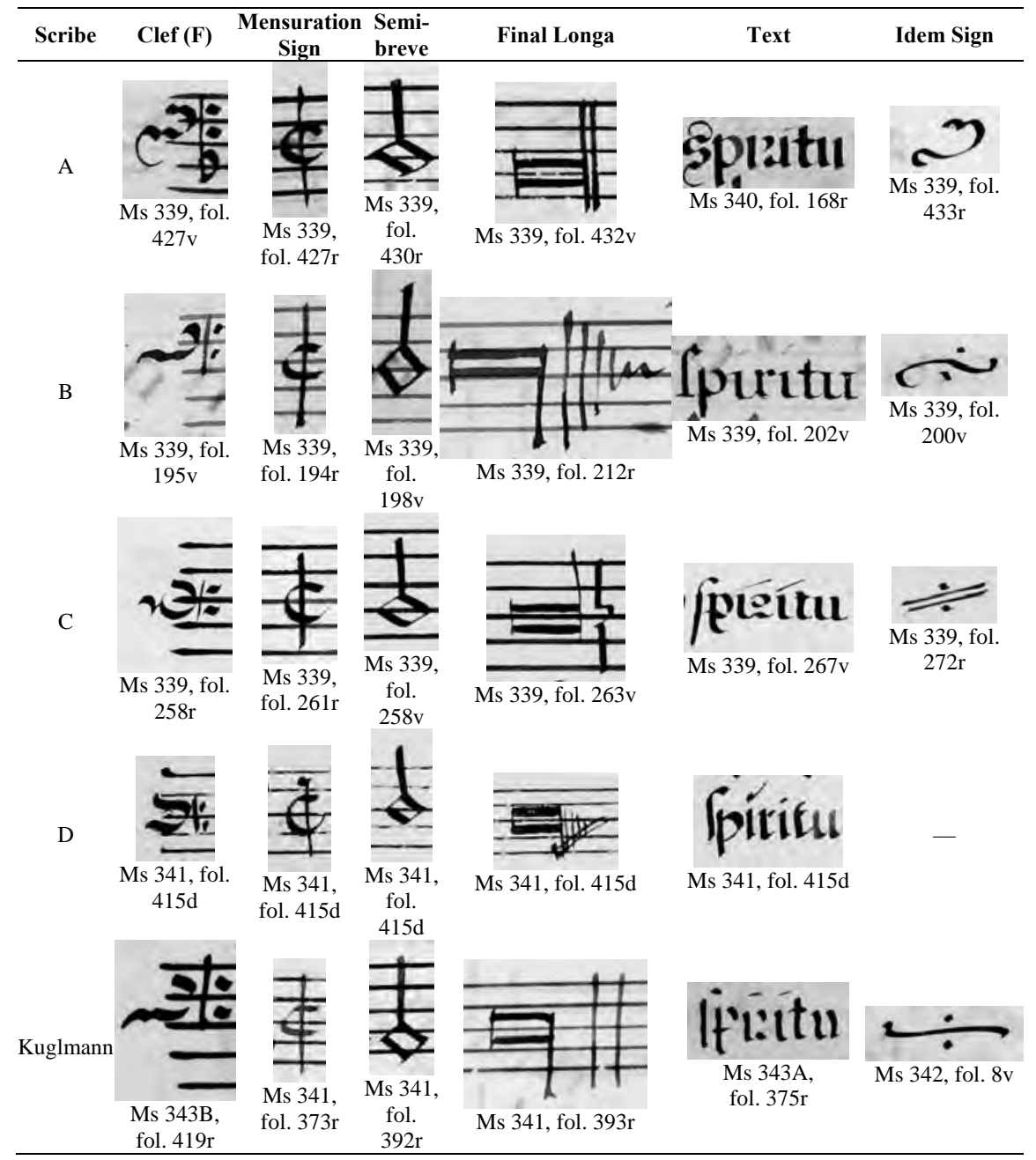




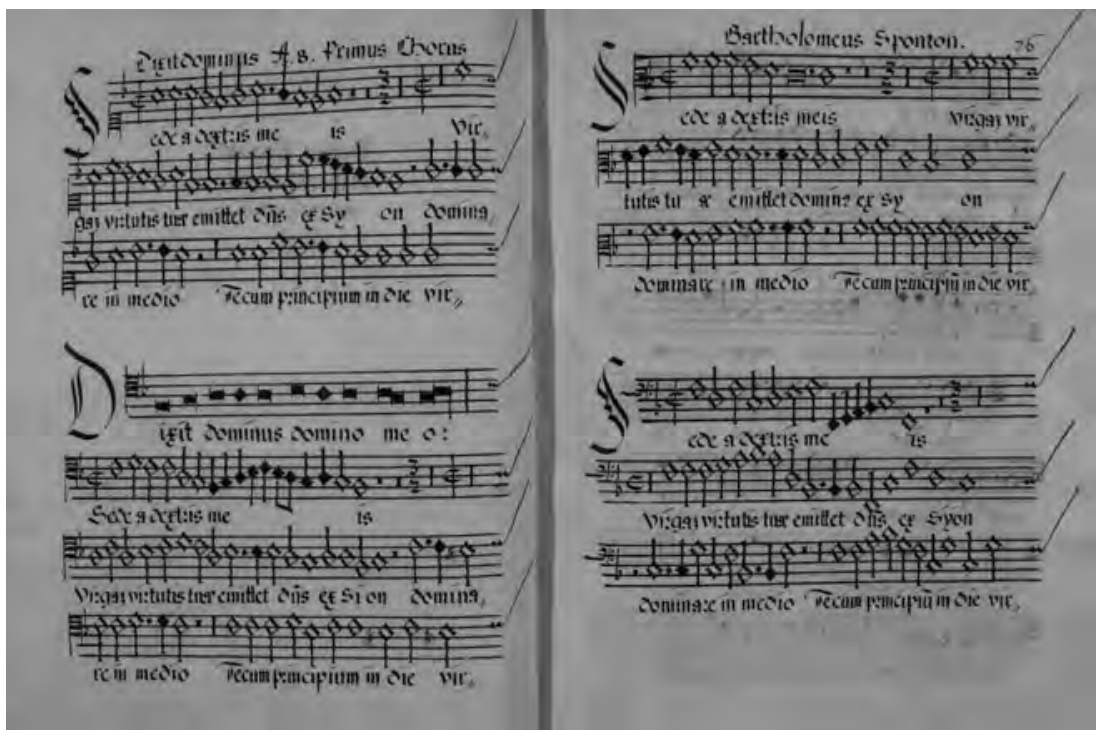

Figure 1 The handwriting of Georg Kuglmann; Bartolomeo Spontone, Dixit Dominus (primus chorus, beginning) (Ljubljana, Narodna in univerzitetna knjižnica, Rokopisna zbirka, Ms 343A, fols. $75 \mathrm{v}-76 \mathrm{r}$; reproduced with kind permission).

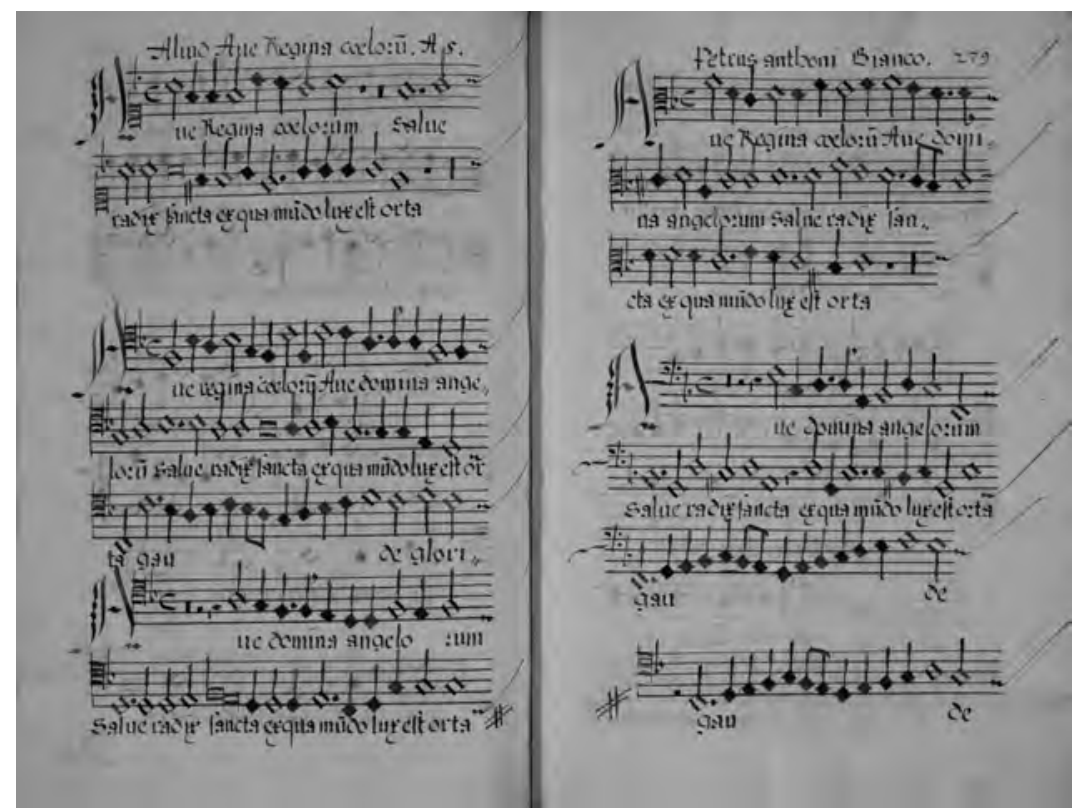

Figure 2 The handwriting of Georg Kuglmann; Pietro Antonio Bianco, Ave Regina (beginning) (Ljubljana, Narodna in univerzitetna knjižnica, Rokopisna zbirka, Ms 344, fols. 278v279r; reproduced with kind permission). 


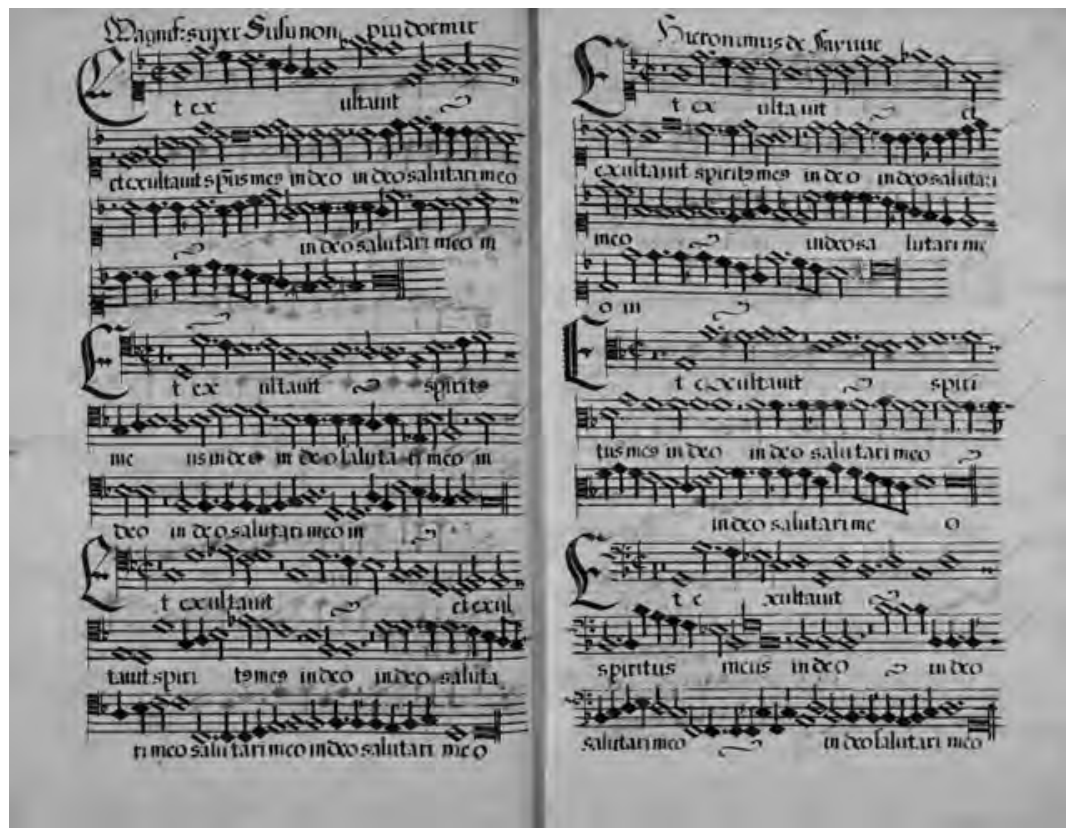

Figure 3 The handwriting of Scribe A; Hieronimus de Sayve, Magnificat Sù sù non più dormir (beginning) (Ljubljana, Narodna in univerzitetna knjižnica, Rokopisna zbirka, Ms 339, fols. $86 \mathrm{v}-87 \mathrm{r}$; reproduced with kind permission).

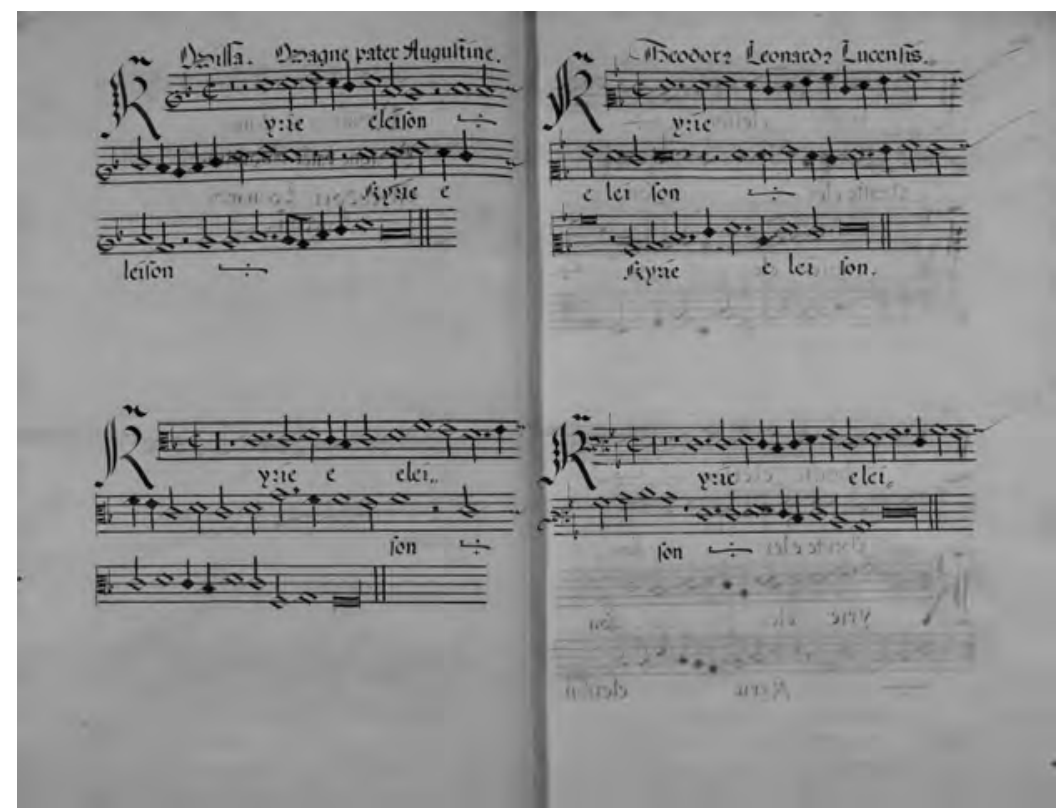

Figure 4 The handwriting of Georg Kuglmann; Theodorus Leonardus, Missa Magne pater Augustine, Kyrie I (Ljubljana, Narodna in univerzitetna knjižnica, Rokopisna zbirka, Ms 339, fols. $104 \mathrm{v}-105 \mathrm{r}$; reproduced with kind permission). 


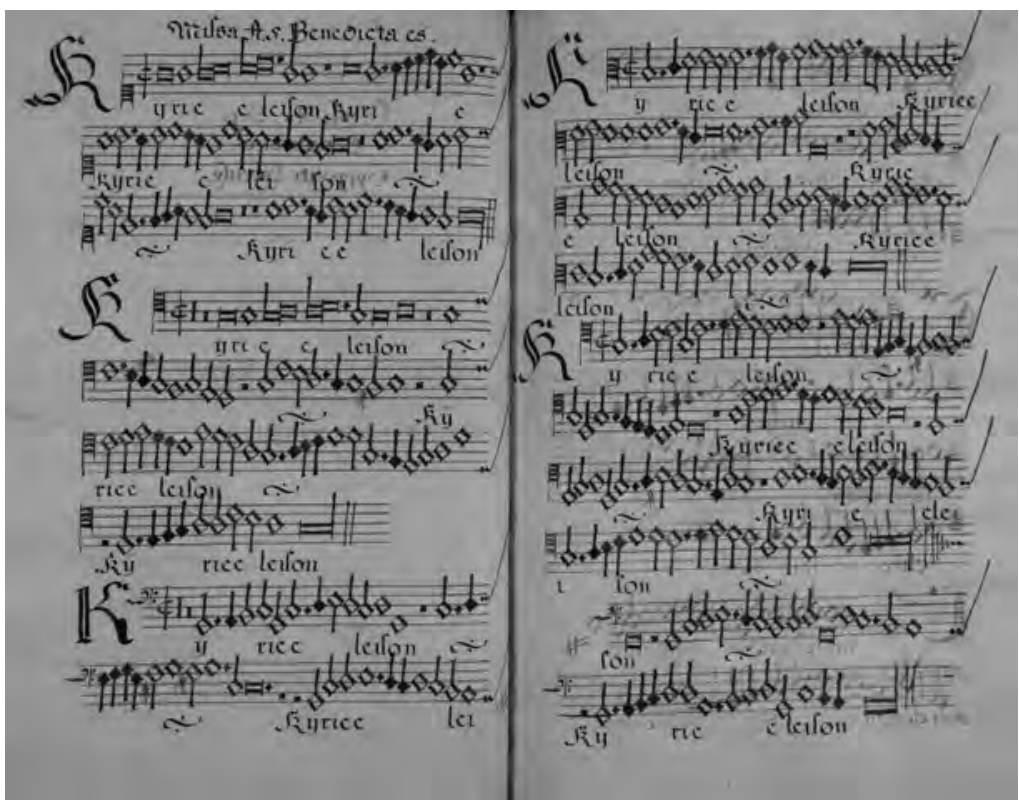

Figure 5 The handwriting of Scribe B; Ippolito Baccusi, Missa Benedicta es, Kyrie I (Ljubljana, Narodna in univerzitetna knjižnica, Rokopisna zbirka, Ms 339, fols. 194v-195r; reproduced with kind permission).

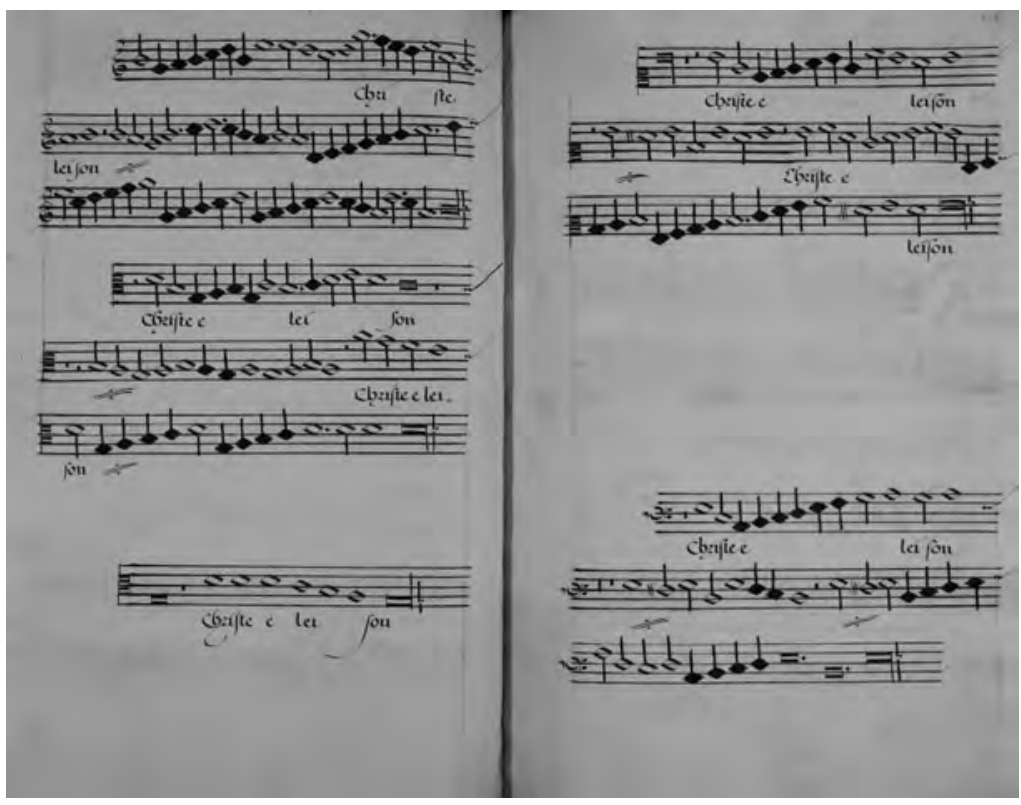

Figure 6 The handwriting of Scribe C; Giovanni Pierluigi da Palestrina, Missa L'homme armé, Christe (end) (Ljubljana, Narodna in univerzitetna knjižnica, Rokopisna zbirka, Ms 339, fols. 257v-258r; reproduced with kind permission). 
In Ms 340 two hands are in evidence. The volume is divided fairly equally between Scribe A (see Fig. 7) and Kuglmann (see Fig. 8); the two men evidently alternated regularly: one copied the first Mass, the other the second Mass, and so forth.

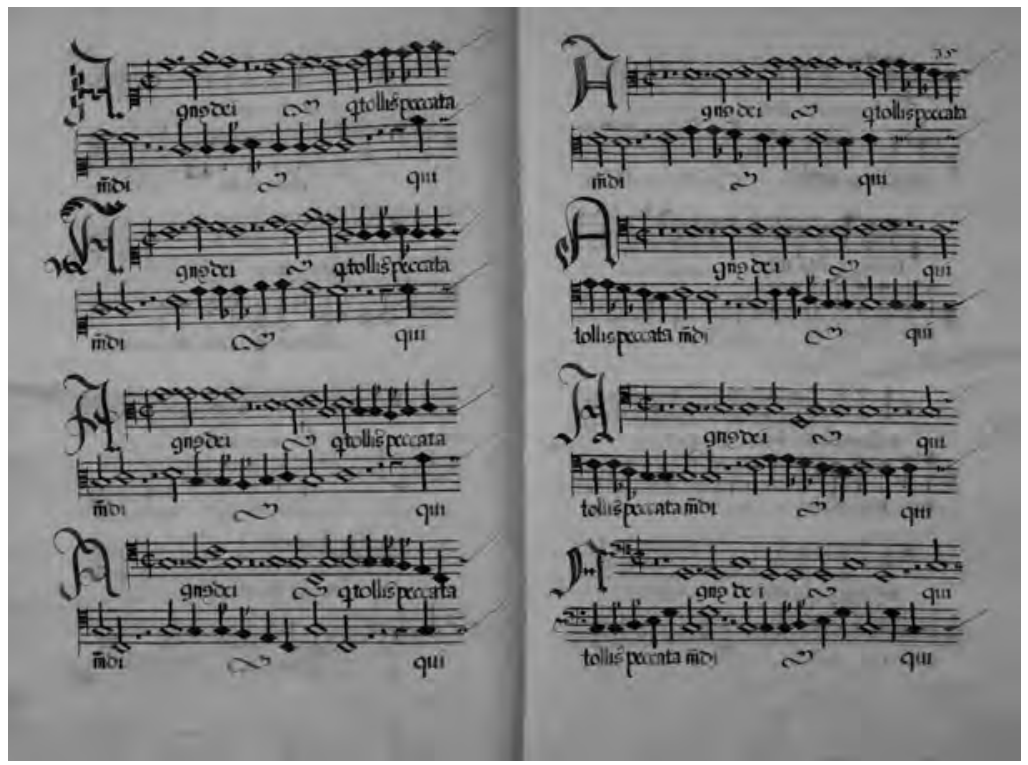

Figure 7 The handwriting of Scribe A; Annibale Perini, Missa Benedicite omnia opera Domini, Agnus Dei (beginning) (Ljubljana, Narodna in univerzitetna knjižnica, Rokopisna zbirka, Ms 340, fols. 34v-35r; reproduced with kind permission).

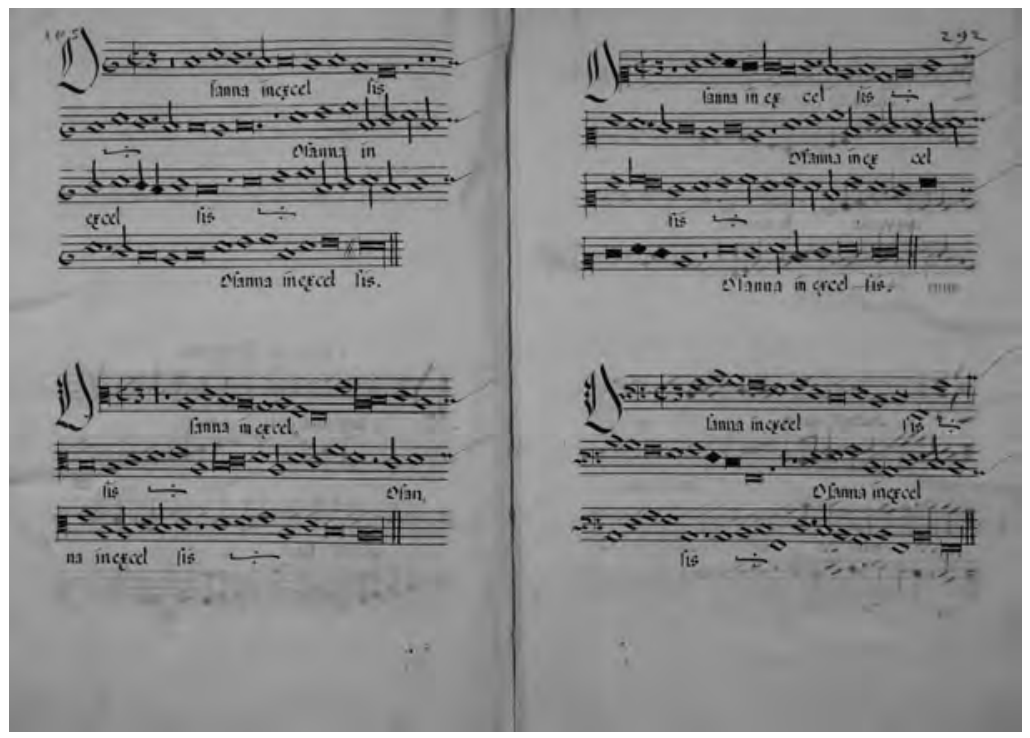

Figure 8 The handwriting of Georg Kuglmann; Johannes de Cleve, Missa Vivre ne puis, Osanna (Ljubljana, Narodna in univerzitetna knjižnica, Rokopisna zbirka, Ms 340, fols. 291v-292r; reproduced with kind permission). 
In Ms 341 three hands are in evidence. The music of the first twenty-two compositions was copied by Kuglmann, while the text was entered by Scribe A (see Fig. 9). Interestingly, both the music and the text of the altus on fol. 242 is the work of Scribe A (see Fig. 10). The next piece (both text and music) was copied by Kuglmann, but at the end of the piece Kuglmann and Scribe A alternate, each entering the text on a single page, one after the other (see Fig. 11). The next section of the manuscript was copied by Kuglmann. After that a few responses in falsobordone style are written in a hand completely different from the others (Scribe D; see Fig. 12). The remainder of the manuscript is once again in Kuglmann's hand.

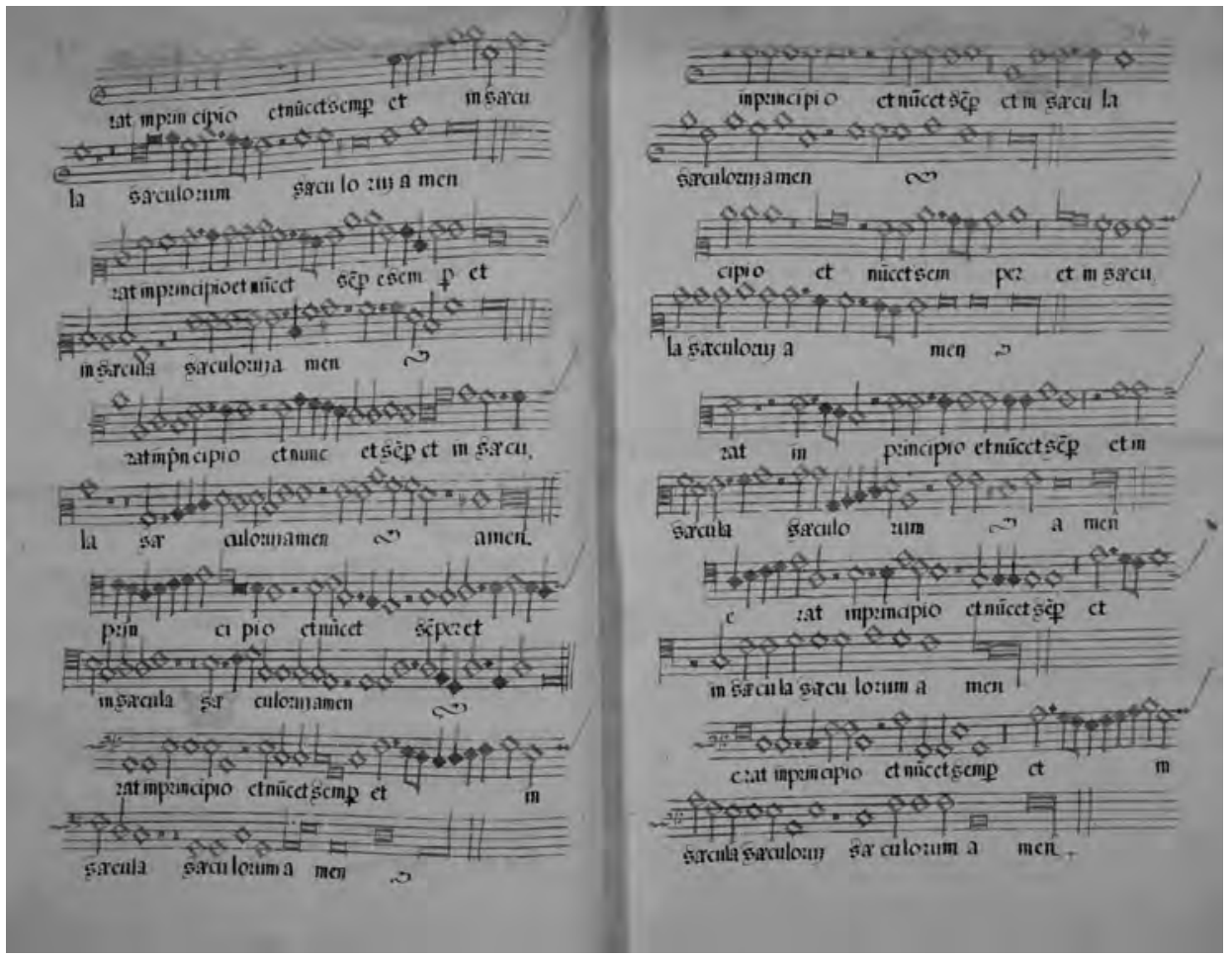

Figure 9 Handwritings of Georg Kuglmann (music) and Scribe A (text); Orlando di Lasso, Magnificat septimi toni a 10 (end) (Ljubljana, Narodna in univerzitetna knjižnica, Rokopisna zbirka, Ms 341, fols. 33v-34r; reproduced with kind permission).

Ms 342 is once again the work of two scribes. The first Mass is copied by Kuglmann (see Fig. 13), the second by Scribe A (see Fig. 14).

What can be gleaned from the above brief observations? Who were the scribes of the choirbooks besides Kuglmann? 


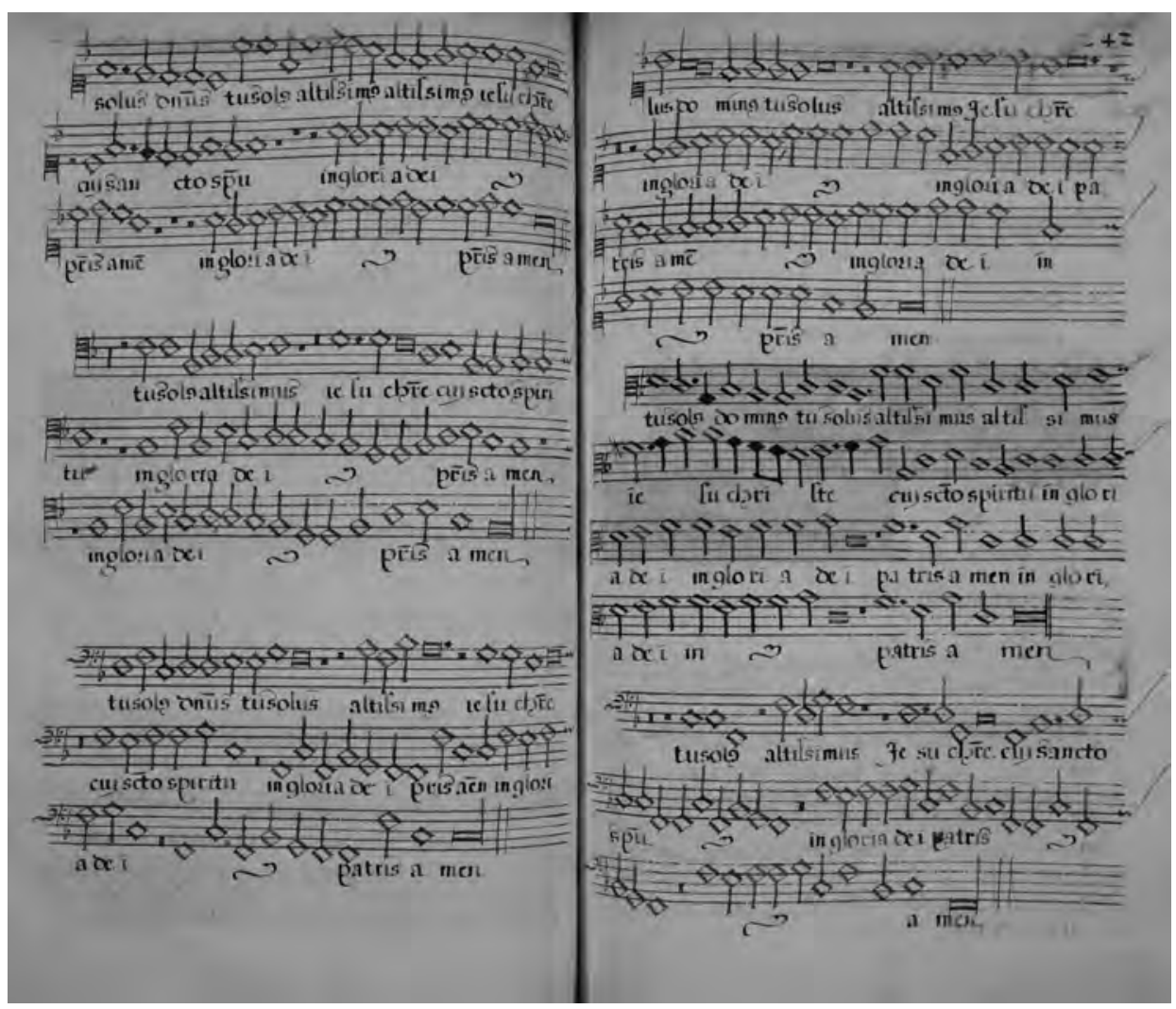

Figure 10 Handwritings of Georg Kuglmann (music) and Scribe A (text and music of the altus); Andrea Gabrieli, Missa Pater peccavi, Gloria (end) (Ljubljana, Narodna in univerzitetna knjižnica, Rokopisna zbirka, Ms 341, fols. 241v-242r; reproduced with kind permission).

It is known that there were other scribes among the musicians at Graz court. ${ }^{13}$ However, none is mentioned as being a music scribe in the Hofkammerakten. The system of division between Scribe A, Scribe B and Kuglmann is interesting; it appears that they worked in close collaboration and were therefore contemporaries. But what about Scribes C and D? As the interpolation of responses in falsobordone style occurs in the space left void at the end of Gatto's Magnificat primi toni, it appears that Scribe D must have entered those responses at some later stage, after the original corpus had been copied. When exactly this was done is impossible to establish. Since the responses are not listed in the index, perhaps they were added at a time when the codex had already reached Ljubljana.

The case of Scribe $\mathrm{C}$ is rather more complicated. It is interesting that the work copied is a Mass by Palestrina, since Palestrina's Masses are otherwise completely absent from many of the sources of Graz origin preserved today. That fact implies that this layer of

${ }^{13}$ See, for example, Federhofer, Musikpflege und Musiker am Grazer Habsburgerhof, 163. 


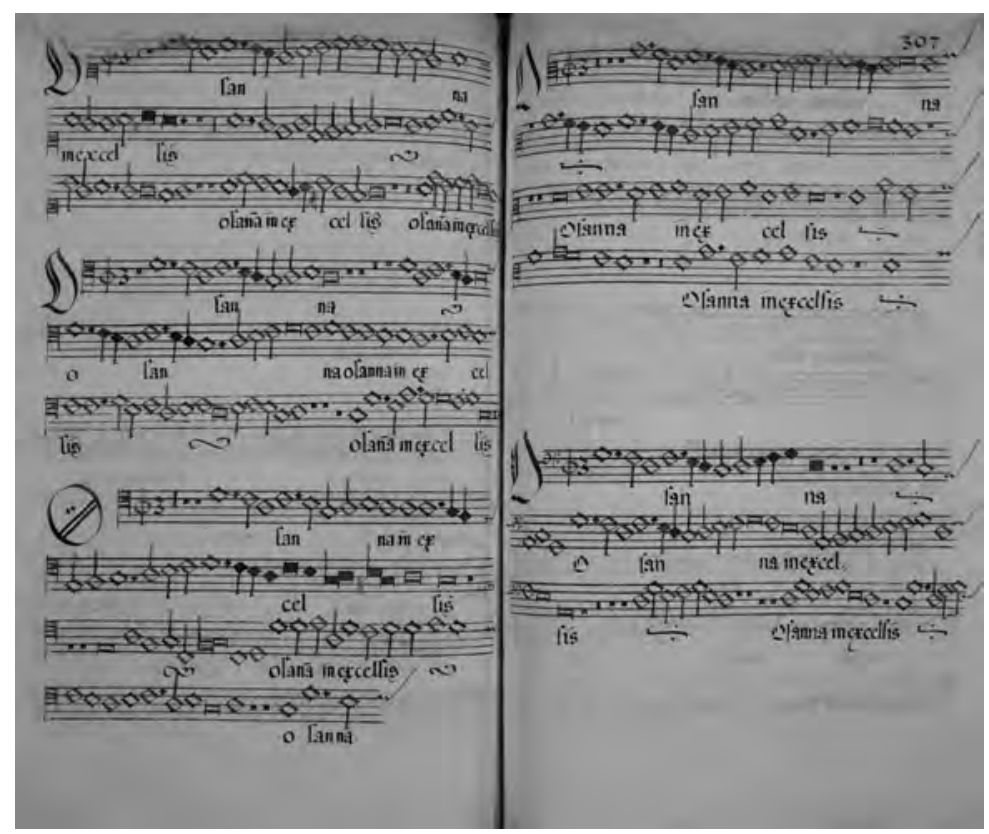

Figure 11 Handwritings of Georg Kuglmann (music and text on the recto) and Scribe A (text on the verso); Jacobus Vaet, Missa quodlibetica, Osanna (Ljubljana, Narodna in univerzitetna knjižnica, Rokopisna zbirka, Ms 341, fols. 306v-307r; reproduced with kind permission).

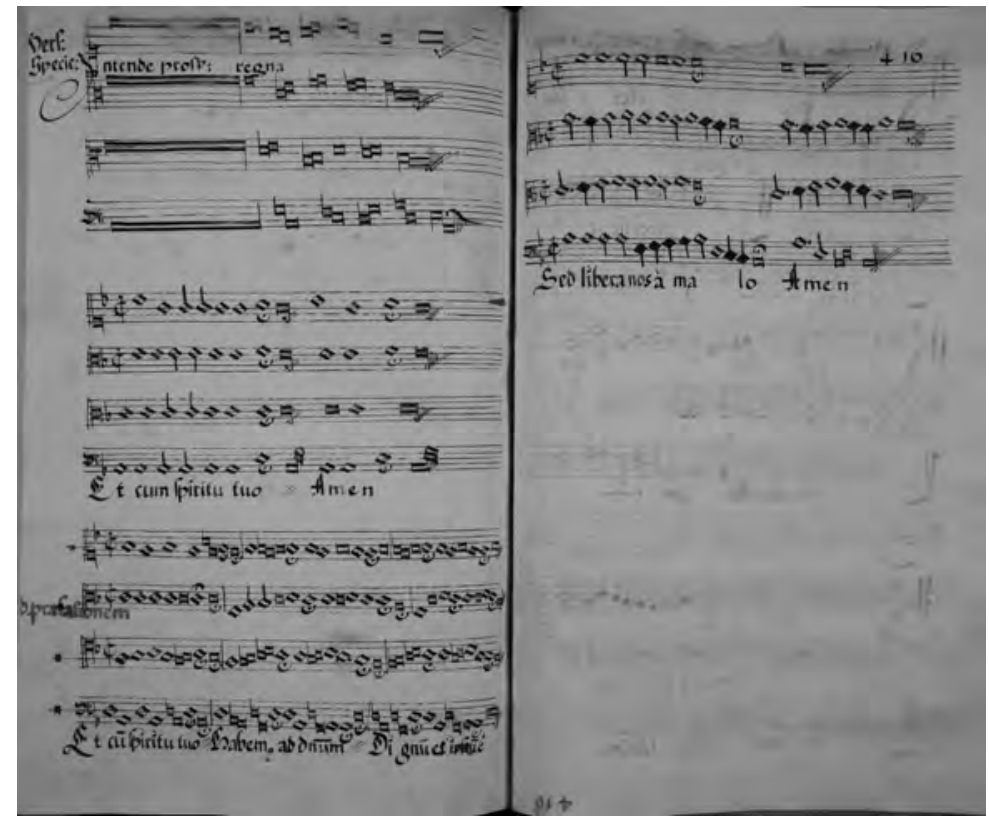

Figure 12 The Handwriting of Scribe D; Falsobordoni (Ljubljana, Narodna in univerzitetna knjižnica, Rokopisna zbirka, Ms 341, fol. 415d-416r; reproduced with kind permission). 


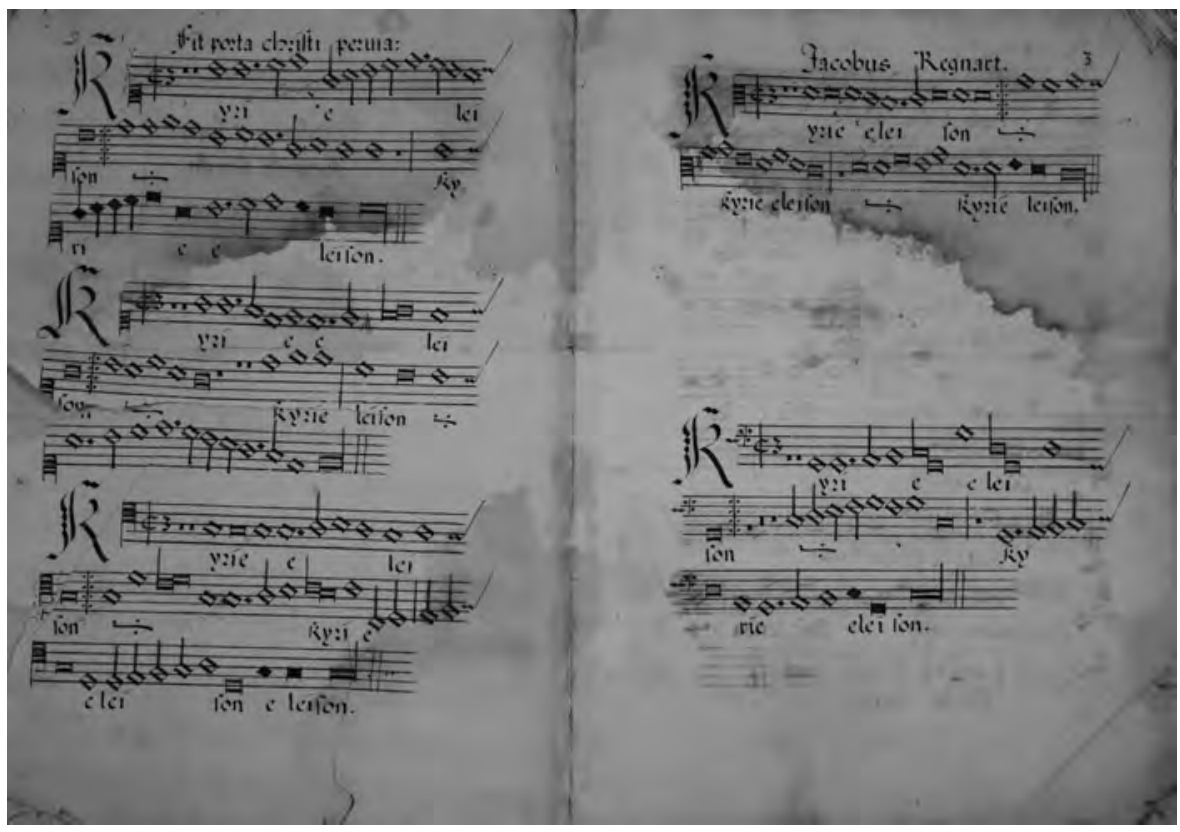

Figure 13 The handwriting of Georg Kuglmann; Jacob Regnart, Missa Fit porta Christi pervia, Kyrie I (Ljubljana, Narodna in univerzitetna knjižnica, Rokopisna zbirka, Ms 342, fols. $2 \mathrm{v}-3 \mathrm{r}$; reproduced with kind permission).

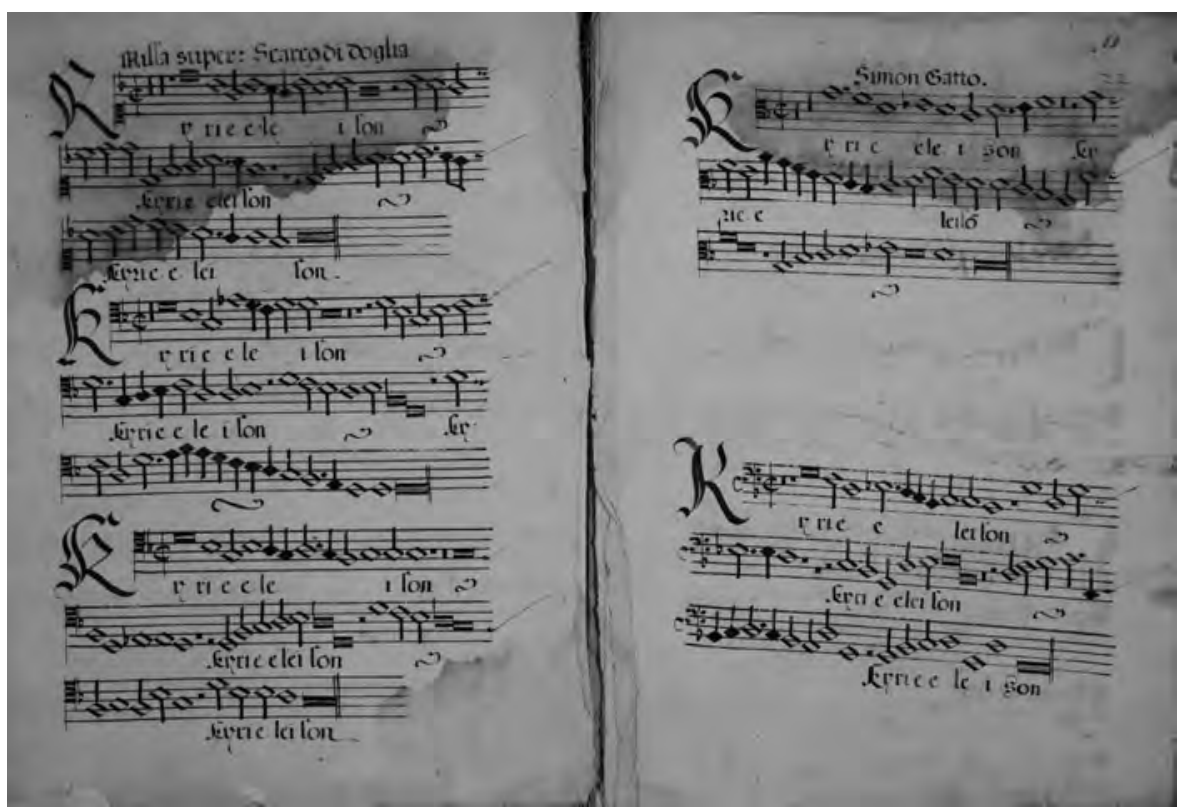

Figure 14 The handwriting of Scribe A; Simone Gatto, Missa Scarco di doglia, Kyriel (Ljubljana, Narodna in univerzitetna knjižnica, Rokopisna zbirka, Ms 342, fols. 21v-22r; reproduced with kind permission). 
Ms 339 has a different origin from the rest of the codex. To discover its possible origin, the paper type it employs has to be examined.

The watermark that appears most frequently by far in the Hren choirbooks is a largesnake design (see Fig. 15), very similar to Briquet 13808. This is a type documented in the German-speaking lands in the last quarter of the sixteenth century and approximately the first decade of the seventeenth century. This paper type was used extensively by Kuglmann throughout his active period as a scribe and was employed also for Ms 339.

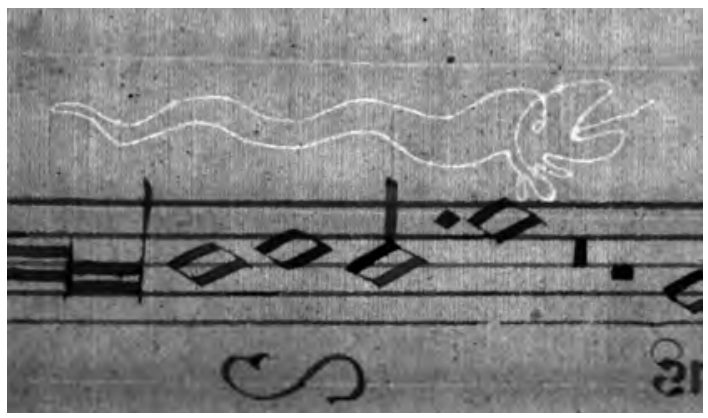

Figure 15 A large-snake watermark (Ljubljana, Narodna in univerzitetna knjižnica, Rokopisna zbirka, Ms 340, fol. 258 (detail); reproduced with kind permission).

However, Scribe C used different paper. The paper of the Palestrina layer (see Fig. 16) is not otherwise represented in the large choirbooks of Graz origin. The watermark - a circle enclosing the letter K (similar to Briquet 8268) - places the source of the paper in Kempten, as Lilian P. Pruett has established, this being one of several paper-producing communities in the Allgäu, Bavaria, just across the border from Tyrol. The Kempten papermill was the principal source of the official and personal paper supplies for Ferdinand II of Tyrol from 1565 to the early 1590s, after which the Tyrolean chancellery began to purchase paper from a mill in Wattens, Tyrol. ${ }^{14}$ The choirbooks known to come from the other Habsburg Kapellen do not employ this paper. However, it was widely used between 1578 and 1595 in Augsburg by Johannes Dreher, a scribe at the monastery of SS. Ulrich and Afra, and is also traceable in Munich. ${ }^{15}$

The watermark of the just-discussed layer of Ms 339 thus suggests three possible places of origin: Augsburg, Munich and Innsbruck. The scribal hands in Dreher's manuscripts and the Munich choirbook differ greatly from the one in Ms 339. The sources from Innsbruck, however, are almost entirely lost, making it impossible to compare all the scribal hands. However, there is a fact that speaks in favour of an Innsbruck provenance for the Palestrina layer. One of Kuglmann's colleagues, Johann Faber from Carniola, a bassist at the Graz court, is documented as a music scribe at the Innsbruck court from 1564 to 1595. ${ }^{16}$ It therefore seems plausible that Faber copied Palestrina's Mass in Innsbruck and brought it with him to Graz, where it was included in Ms 339. ${ }^{17}$

${ }^{14}$ Pruett, "Little-Known Renaissance Polyphonic Hymn Cycle," 832-833.

${ }^{15}$ Munich, Bayerische Staatsbibliothek (D-Mbs), Mus.ms. 79, from ca. 1580, evidences use of the same paper.

${ }^{16}$ Tschmuck, Die höfische Musikpflege in Tirol, 61.

${ }^{17}$ As the Innsbruck and Graz courts had close ties, it could well have been sent from Innsbruck 
Figure 16 K-in-circle watermark (Ljubljana, Narodna in univerzitetna knjižnica, Rokopisna zbirka, Ms 339, fol. 288 (detail); reproduced with kind permission).

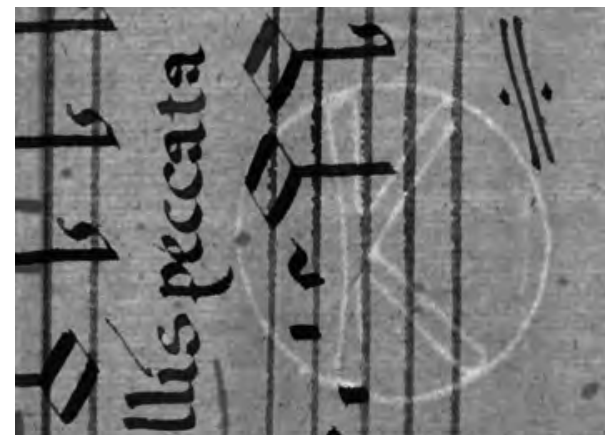

Let us try now to draw some conclusions about the origin of the Hren choirbooks, on the basis of the above observations.

The organization of the Hren choirbooks is fairly clear; the contents being grouped by type of composition and number of voices. Despite their obvious rigorous organization, the copying was not executed continuously from the first folio to the last but was, rather, a more complex operation entailing the copying of different layers at different times (even in Ms 343, entirely written out by Kuglmann, there is evidence of one layer being copied well before the rest of the manuscript).

From the paleographical characteristics of the codices we may deduce that there probably existed a scribal workshop in Graz responsible for copying and compiling the Hren choirbooks. But codicological and repertorial evidence shows that one small section of Ms 339 was of different provenance, its most probable place of origin being Innsbruck. Moreover, while the main part of Ms 339 appears to date from the early seventeenth century, the watermark of the Palestrina layer shows this part of the codex to be a little older, thus to have a prehistory.

So the Hren choirbooks are typical products of their era. They are a collection of manuscripts containing liturgical music by local composers as well as works imported from elsewhere. As typically occurs, the work of several scribes can be detected: these were professional copyists working in a scribal workshop that produced many choirbooks, only a handful of which, unfortunately, have survived up to the present day.

to Graz already before 1595, when Archduke Ferdinand II of Tyrol died and the Kapelle was consequently disbanded. 


\section{Sources}

Graz, Universitätsbibliothek Graz (A-Gu), Mss 8 and 22.

Ljubljana, Narodna in univerzitetna knjižnica, Rokopisna zbirka (SI-Lnr), Mss 339-344.

Munich, Bayerische Staatsbibliothek (D-Mbs), Mus.ms. 79.

\section{Bibliography}

Bischoff, Ferdinand. "Beiträge zur Geschichte der Musikpflege in Steiermark." Mittheilungen des historischen Vereines für Steiermark 37 (1889): 98-166.

Federhofer, Hellmut. Musikpflege und Musiker am Grazer Habsburgerhof der Erzherzöge Karl und Ferdinand von Innerösterreich (1564-1619). Mainz: B. Schott's Söhne, 1967.

Gruber, Gernot. "Magnificatkompositionen in Parodietechnik aus dem Umkreis der Hofkapellen der Herzöge Karl II. und Ferdinand von Innerösterreich.” Kirchenmusikalisches Jahrbuch 51 (1967): 33-60.

Höfler, Janez. "Gornjegrajska glasbena zbirka in inventarij ljubljanskega stolnega kora iz leta 1620.” In Glasbena umetnost pozne renesanse in baroka na Slovenskem, 32-35. Ljubljana: Partizanska knjiga, 1978.

____ and Ivan Klemenčič. Introduction to Glasbeni rokopisi in tiski na Slovenskem do leta 1800: katalog / Music Manuscripts and Printed Music in Slovenia before 1800: Catalogue, 10-14. Ljubljana: Narodna in univerzitetna knjižnica, 1967.

Kokole, Metoda. "From Graz to Today's Central Slovenia: The Influence of Italian Polychoral Music in the Period c. 1595 to c. 1620.” In La musica policorale in Italia e nell'Europa centro-orientale fra Cinque e Seicento / Polychoral Music in Italy and in Central-Eastern Europe at the Turn of the Seventeenth Century, edited by Aleksandra Patalas and Marina Toffetti, 335-374. TRA.D.I.MUS., Studi e monografie 1. Venice: Edizioni Fondazione Levi, 2012.

Kurtzman, Jeffrey, and Anne Schnoebelen. A Catalogue of Mass, Office, and Holy Week Music Printed in Italy, 1516-1770. JSCM Instrumenta 2. Accessed 13 April 2015. http://sscm-jscm.org/instrumenta/vol-2/.

Pruett, Lilian. "A Little-Known Renaissance Polyphonic Hymn Cycle of the Habsburg Court.” In Musica antiqua 8/1: Acta musicologica, 803-836. Bydgoszcz: Filharmonia Pomorska im. Ignacego Paderewskiego, 1988.

Snoj, Jurij. Zgodovina glasbe na Slovenskem. Vol. 1, Glasba na Slovenskem do konca 16. stoletja. Ljubljana: Založba ZRC, 2012.

Škulj, Edo. Hrenove korne knjige. Ljubljana: Družina, 2001.

Tschmuck, Peter. Die höfische Musikpflege in Tirol im 16. und 17. Jahrhundert: eine sozioökonomische Untersuchung. Bibliotheca musicologica - Universität Innsbruck 5. Innsbruck: Studienverlag; Lucca: Libreria musicale italiana, 2001.

Zotter, Hans. "Der Handschriftenkatalog der UB Graz.” Sondersammlungen an der UB Graz. Accessed 9 April 2015. http://sosa2.uni-graz.at/sosa/katalog/. 


\section{IZ GRADCA V LJUBLJANO? \\ NA POTI K IZVORU HRENOVIH KORNIH KNJIG}

\section{Povzetek}

Med najpomembnejše glasbene rokopise s konca 16. in začetka 17. stoletja, ohranjene v slovenskih knjižnicah in arhivih, sodi šest velikih kornih knjig, ki jih danes hrani Glasbena zbirka Narodne in univerzitetne knjižnice v Ljubljani (Ms 339-Ms 344). Rokopisi vsebujejo liturgično glasbo (predvsem maše in uglasbitve kantika Magnificat, pa tudi litanije, himne, marijanske antifone in psalme) italijanskih in frankoflamskih skladateljev, ki so vsaj nekaj časa delovali v južnem, katoliškem delu nemško govorečega področja. Med njimi so tako imena slavnih mojstrov 16. stoletja (npr. Orlando di Lasso, Philippe de Monte in Giovanni Pierluigi da Palestrina) kot tudi popolnoma neznanih skladateljev (npr. Hieronymus de Sayve). Korne knjige so v prvih desetletjih 17. stoletja prešle v last ljubljanskega knezoškofa Tomaža Hrena (škof v letih 1597-1630), tesno povezanega z graškim dvorom. Po njem se tako omenjeni rokopisi navadno imenujejo Hrenove korne knjige.

Hrenovi kodeksi so že bili predmet preučevanja, a z omejenimi izsledki. Iz ene izmed knjig je razvidno, da je bil njihov glavni pisec graški dvorni basist Georg Kuglmann in da so bile torej v večjem delu napisane v Gradcu. Vendar pa je prisotnih več različnih pisav, prav tako je raznoroden papir, iz katerega je mogoče razbrati različne vodne znake. Različni pisci in vodni znaki nakazujejo, da repertoar ni bil v celoti prepisan v Gradcu, a je bil tam najverjetneje kompiliran. Poleg Kuglmannove pisave se v kodeksih pojavljajo še štiri druge neznane pisave. Tri pisave (med njimi Kuglmannova) se med seboj prepletajo in kažejo na obstoj delavnice v Gradcu. Ostali dve pisavi pa nakazujeta, da repertoar ni bil v celoti prepisan v Gradcu. Kot kaže uporabljen papir (z vodnim znakom), je bila Palestrinova Missa L'homme armé najverjetneje proti koncu 16. stol. prepisana V Innsbrucku, kratki odpevi v slogu falsobordone pa so bili dodani naknadno (na kar mdr. kaže njihova umestitev na prazni dve strani enega izmed kodeksov), morda celo v Ljubljani. 